\title{
Growth and production of monosex tilapia (oreochromis niloticus) under different feeding frequencies in pond conditons
}

\begin{abstract}
An experiment was conducted to study the effect of feeding frequency on growth and production of monosex tilapia (Oreochromis niloticus) in Reliance Aqua Farm, Rahmatpur, Mymensingh for a period of four months from $7^{\text {th }}$ July to $4^{\text {th }}$ November, 2012. Ponds were equal in size which was categorized in three treatments viz. $\mathrm{T}_{1}, \mathrm{~T}_{2}$ and $\mathrm{T}_{3}$ with each two replicates. A stocking density of 200 fish per decimal with three feeding frequency four times in a day $\left(\mathrm{T}_{1}\right)$, three times in a day $\left(\mathrm{T}_{2}\right)$ and two times in a day $\left(\mathrm{T}_{3}\right)$ were used was used for the experiment. The fry were initially fed at $30 \%$ of their body weight and the rate was reduced to $5 \%$ gradually at the final week.

The proximate composition of the experimental diet ( $\%$ dry matter basis) was moisture $12.14 \%$, protein $27.94 \%$, lipid $7.95 \%$, ash $15.38 \%$ and NFE $36.59 \%$. The water quality parameters were more or less similar in three treatments and remained within the suitable ranges for aquaculture. The mean weight gain 323.68, 294.55 and 244.72 g, percent weight gain 5678.65, 5167.54 and 4293.27, SGR 3.38, 3.30 and 3.15\%, respectively were recorded in $\mathrm{T}_{1}, \mathrm{~T}_{2}$ and $\mathrm{T}_{3}$, respectively. The highest weight gain, percent weight gain and SGR were showed in $T_{1}$ having the feeding frequency four times a day and lowest was found in $\mathrm{T}_{3}$ having feeding frequency two times a day.

The survival rate was $94.75,93.0$ and $90.5 \%$ in $\mathrm{T}_{1}, \mathrm{~T}_{2}$ and $\mathrm{T}_{3}$, respectively. The best FCR value was obtained in $T_{1}$ where fry were fed with four times feeding frequency. The significantly $(\mathrm{P}<0.01)$ highest fish production was $62.42 \mathrm{~kg} / \mathrm{dec} / 4$ months in $\mathrm{T}_{1}$ and production was found to be decreased significantly with the decrease in feeding frequencies. The lowest fish production was $45.33 \mathrm{~kg} / \mathrm{dec} / 4$ months in $\mathrm{T}_{3}$. The result of the present study demonstrated that four times feeding frequency played better effect on the growth and production performance of monosex male tilapia (Oreochromis niloticus).
\end{abstract}

Keywords: Growth, Production, Survival, Feeding frequency, Monosex tilapia
Volume 6 Issue $5-2017$

\author{
Abu Zafar, ${ }^{2}$ Mahfujul Karim,' Mohsin Ali' \\ 'Department of Aquaculture Bangladesh Agricultural University \\ Bangladesh \\ ${ }^{2}$ Department of Aquaculture Hajee Mohammad Danesh Science \\ Technology University Bangladesh
}

Correspondence: Abu Zafar Assistant Professor Department of Aquaculture Hajee Mohammad Danesh Science Technology University Bangladesh, Email zafaraqc@hstu.ac.bd

Received: October 29, 2017 | Published: November 30, 2017

\section{Introduction}

With increase in human population and diminished natural fisheries resources, aquaculture is rapidly gaining importance. But, fish culture on a small-scale basis has often failed due to inadequate knowledge regarding ideal stocking density and feeding regime of fish.

The commercial feasibility of any intensively cultured fish species depends on market demand and cost of production. The largest section of the production cost lies in feed, with protein containing the most expensive component. ${ }^{1-2}$

However, to improve fish culture at commercial level, it is important to establish an appropriate feeding management strategy that is based on identification of the daily feeding patterns or rhythms. ${ }^{3-4}$ It is well known that the amount and timing of feeding play an important role in growth and feed utilization efficiency. ${ }^{5-8}$ In aquaculture, like other form of husbandry, feeding is crucial for its viability and success. ${ }^{9}$ Feed cost is one of the largest operational costs in aquaculture. ${ }^{10}$

The practice of feeding in an aquaculture system involves selection of appropriate ration sizes, (the amount of feed supply), determining the feeding frequency (how many times the organism should be fed in a day), and timing of meal and efficient broadcasting of the predetermined ration to the culture system. ${ }^{11}$ The number of feeding per day and the time of feeding vary with species, size of fish and environmental conditions. ${ }^{12}$ Sometimes excellent quality feeds do not perform satisfactorily unless correct feeding practices and proper feeding rates are used..$^{13}$ It is essential to recommend the optimum feeding rate for economic production of fish. In general the feeding regime and growth of fish are very much related. Thus the feeding strategy may provide clue for maximum growth because the feeding frequency contribute to feed efficiency and growth response. ${ }^{14}$

Tilapia (Oreochromis niloticus) is known as commercially important food fishes for aquaculture throughout several regions of the world such as China, South-east Asia, Africa, USA and Latin America/Caribbean. ${ }^{15-16}$ Tilapia is an excellent fish for growing in the shallow and seasonal ponds in a country like Bangladesh ${ }^{17-18}$ as it enjoys suitable climate and ecological conditions for culture of this warm water species. Thus, culture of monosex tilapia might prove effective to induce a positive approach towards tilapia culture in Bangladesh.

Based on the above aforementioned context, this experiment was conducted to determine the growth performance of monosex male tilapia at different feeding frequency and find out the effective feeding frequency to increase the production in ponds.

\section{Materials and methods}

The experiment was conducted in six ponds situated in the Reliance Aqua Farm, Rahmatpur, Sadar, Mymensingh for a period of four months commencing from $7^{\text {th }}$ July to $4^{\text {th }}$ November, 2012. 
The water of the ponds were drained and kept for sundry about a week. All gates and pipes were checked for broken slabs and other parts. Repair screens to prevent predators and pests from entering the pond system. All aquatic weeds were removed manually from the ponds. Complete eradication of all undesirable fish, insects and other aquatic life forms were done by using phostoxin tablet (3g per tablet, Organic Pharmaceuticals Limited) at the rate of six tablets per decimal. After a few hours of phostoxin tablet administration the dead organisms were collected from the ponds by repeated netting and buried into the soil in order to prevent unwanted contamination and pollution. One week after weeds, pests and predator control, lime was administrated at a rate of $1 \mathrm{~kg} / \mathrm{dec}$. Seven days after liming; the ponds were fertilized with cow dung, urea and triple super phosphate (TSP) at the rate of $3 \mathrm{~kg}, 100 \mathrm{~g}$ and $75 \mathrm{~g} / \mathrm{dec}$, respectively. After a week of fertilization the water was tested for natural food.

Ponds were divided into three treatments Viz. $\mathrm{T}_{1}, \mathrm{~T}_{2}$, and $\mathrm{T}_{3}$ each having two replications. The size of the each pond was 16 decimal. The Monosex Tilapia fry were stocked @ 200/decimal for each treatment and the fry were initially fed @ 30\% of their body weight and was reduced gradually to $5 \%$ of their body weight at the final week. Reducing of ration size was performed by $1 \%$ in each 15 days interval. The fish were fed four times a day in $\mathrm{T}_{1}$, three times a day in $\mathrm{T}<\mathrm{sub}>1</$ sub $>$ and two times a day in $\mathrm{T}_{3}$, respectively. Pelleted feed (MEGA Feed) was broadcasted in a fixed corner of each pond. Three major water quality parameters such as temperature, dissolved oxygen and $\mathrm{pH}$ were measured and recorded every 15 days interval throughout the experimental period at 9 am by using a commercial kit box (Model: FF-3, USA).Proximate compositions of the experimental feed were analyzed in triplicate according to standard procedures given in Association of official Analytical Chemist ${ }^{19}$ The parameters are:

$$
\text { Moisture }=\frac{(\mathrm{Y}-\mathrm{Z})}{\mathrm{S}} \times 100
$$

Where,

$\mathrm{S}=$ Sample weight

$\mathrm{Y}=$ Sample + crucible weight

$\mathrm{Z}=$ Dry sample + crucible weight

Crude Protein:

$\%$ Nitrogen $=\frac{\text { Milliequivalent of nitrogen }(0.014) \mathrm{ml} \times \text { Stregth of HCL } \times 100}{2}$ Sample weight gain $(\mathrm{g})$

Percent crude protein $=\%$ Nitrogen $\times 6.25$

$$
\text { Lipid }(\%)=\frac{\text { Weight of lipid }}{\text { Weight of Sample gain }} \times 100
$$

Ash content $(\%)=\frac{\text { Weight of ash }(\mathrm{g})-\text { Weight of empty crucible }(\mathrm{g})}{\text { Weight of sample }(\mathrm{g})} \times 100$

Crude fiber $(\%)=\frac{\text { weight of sample after air dry }(\mathrm{g}) \text {-weight of sample after ashing }(\mathrm{g})}{\text { Sample weight }(\mathrm{g})} \times 100$

NFE $(\%)=100 \%($ moisture + crude protein + lipid + ash $)$

Growth and production of fishes were measured by sampling

at an interval of 15 days by using a digital electronic balance and were evaluated by the following parameters.

Weight gain= mean final fish weight- mean initial weight.
$\%$ weight gain $=\frac{\text { Mean final fish weight }(\mathrm{g})-\text { mean initial fish weight }(\mathrm{g})}{\text { mean initial fish weight }(\mathrm{g})} \times 100$

$$
\operatorname{SGR}(\% \text { per day })=\frac{\log _{\mathrm{e}} \mathrm{W}_{2}-\log _{\mathrm{e}} \mathrm{W}_{1}}{\mathrm{~T}_{2}-\mathrm{T}_{\mathrm{l}}} \times 100
$$

Where,

$\mathrm{W} 1=$ Initial live body weight $(\mathrm{g})$ at time $\mathrm{T}_{1}$ (day)

$\mathrm{W} 2=$ Final live body weight $(\mathrm{g})$ at time $\mathrm{T}_{2}$ (day)

$\mathrm{T}_{2}-\mathrm{T}_{1}=$ Duration of the experiment (day)

$$
\text { Survival rate }(\%)=\frac{\text { No. of Fish Harvested }}{\text { No. of Fish Stocked }} \times 100
$$

Production $=$ No. of fish harvested $\times$ Final weight of fish

$$
\text { Food Conversion Ratio }(F C R)=\frac{\text { Dry feed Fed }}{\text { Live weight gain }}
$$

Analysis of the data was done by using the software SPSS version 16.0 and significance was assigned at $1 \%$ level of probability.

\section{Results and discussion}

\section{Proximate composition analysis}

To know the acceptability of the feed proximate composition analysis is important. Generally, in all treatments the fish become habituated to the experimental diet within 2- 3 days of feeding (Table 1).

Table I Proximate compositions of the experimental diet (\% dry matter basis)

\begin{tabular}{ll}
\hline Parameters & Amount (\%) \\
\hline Moisture & 12.14 \\
Protein & 27.94 \\
Crude fiber & 5.23 \\
Lipid & 7.95 \\
Ash & 15.38 \\
NFE & 36.59 \\
\hline
\end{tabular}

\section{Water quality parameters}

\section{Water temperature $\left({ }^{\circ} \mathrm{C}\right)$}

During the study period the water temperature varied from 31.7 to $27.5^{\circ} \mathrm{C}$ in $\mathrm{T}_{1}, 31.8$ to $27.2^{\circ} \mathrm{C}$ in $\mathrm{T}_{2}$ and 31.6 to $27.5^{\circ} \mathrm{C}$ in $\mathrm{T}_{3}$. The mean values of water temperature in treatments $\mathrm{T}_{1}, \mathrm{~T}_{2}$ and $\mathrm{T}_{3}$ were $29.52 \pm 1.37, \quad 29.49 \pm 1.51$ and $29.46 \pm 1.36^{\circ} \mathrm{C}$, respectively. The maximum temperature $32^{\circ} \mathrm{C}$ was recorded in treatment $\mathrm{T}_{2}$ on 21 August whereas the minimum $\left(27.1^{\circ} \mathrm{C}\right)$ was in $\mathrm{T}_{2}$ on November 11 .

\section{Dissolved Oxygen}

The dissolved oxygen content of the water was found to vary from 4.55 to $5.75 \mathrm{mg} / 1$ in $\mathrm{T}_{1}, 4.30$ to $6.40 \mathrm{mg} / 1$ in $\mathrm{T}_{2}$ and 4.8 to $5.75 \mathrm{mg} / \mathrm{l}$ in $\mathrm{T}_{3}$. The mean values of dissolved oxygen content of the water in treatment $T_{1}, T_{2}$ and $T_{3}$ were $5.02 \pm 0.53,5.28 \pm 0.65$ and $5.29 \pm 0.34$ $\mathrm{mg} / \mathrm{l}$, respectively. The highest value of dissolved oxygen content $(6.6$ $\mathrm{mg} / \mathrm{l}$ ) was found in $\mathrm{T}_{2}$ on $21^{\text {st }}$ August whereas the lowest value (4.2 $\mathrm{mg} / \mathrm{l}$ ) of dissolved oxygen content was found in $\mathrm{T}_{2}$ on $4^{\text {th }}$ November. No significant variation of dissolved oxygen was observed among the treatments. 


\section{PH}

Variation in the $\mathrm{pH}$ values under different treatments were revealed during study period. The range of $\mathrm{pH}$ values recorded in treatment $\mathrm{T}_{1}$, $\mathrm{T}_{2}$ and $\mathrm{T}_{3}$ were found to vary between 7.135 to $7.650,7.355$ to 8.275 and 7.425 to 7.945 , respectively. The mean values of $\mathrm{pH}$ content of the water in $\mathrm{T}_{1}, \mathrm{~T}_{2}$ and $\mathrm{T}_{3}$ were $7.38 \pm 0.22,7.92 \pm 0.30$ and $7.67 \pm 0.16$, respectively. The highest $\mathrm{pH}(8.3)$ obtained with the treatment $\mathrm{T}_{3}$ on 5th October whereas the lowest $\mathrm{pH}$ value (6.98) was recorded in $\mathrm{T}_{1}$ on $7^{\text {th }}$ July. There was no significant variations of $\mathrm{pH}$ values under different treatments were found and the values were alkaline range during the study period (Table 2).

Table 2 Mean $( \pm S D)$ values of water quality parameters in all treatments throughout the study period

\begin{tabular}{llll}
\hline Treatments & \multicolumn{3}{l}{ Parameters } \\
& Temperature $\left({ }^{\circ} \mathbf{C}\right)$ & $\begin{array}{l}\text { dissolved oxygen }(\mathrm{mg} / \mathrm{I}) \\
\text { pH }\end{array}$ \\
\hline $\mathrm{T}_{1}$ & $29.52 \pm 1.37$ & $5.02 \pm 0.53$ & $7.38 \pm 0.22$ \\
$\mathrm{~T}_{2}$ & $29.49 \pm 1.5 \mathrm{I}$ & $5.28 \pm 0.65$ & $7.92 \pm 0.30$ \\
$\mathrm{~T}_{3}$ & $29.46 \pm 1.36$ & $5.29 \pm 0.34$ & $7.67 \pm 0.16$ \\
\hline
\end{tabular}

\section{Growth performance of fish}

For the assessment of proper growth performance of monosex male tilapia fry in different treatments during experimental period, mean weight gain, percent weight gain, specific growth rate (SGR\% per day), survival (\%), food conversion ratio (FCR) and production (Kg/dec/4 months) were calculated and are shown in Table 3.

Table 3 Growth parameters of monosex tilapia observed during the study period

\begin{tabular}{lllll}
\hline $\begin{array}{l}\text { Growth } \\
\text { parameters }\end{array}$ & Treatment & & & LSD \\
\hline Initial weight $(\mathrm{g})$ & $5.7 \pm 0.00$ & $5.7 \pm 0.00$ & $5.7 \pm 0.00$ & 0.00 \\
Final weight (g) & $329.38 \pm 2.05^{\mathrm{a}}$ & $300.25 \pm 0.87^{\mathrm{b}}$ & $250.42 \pm 2.33^{\mathrm{c}}$ & 2.795 \\
Weight gain (g) & $323.68 \pm 2.05^{\mathrm{a}}$ & $294.55 \pm 0.87^{\mathrm{b}}$ & $244.72 \pm 2.33^{\mathrm{c}}$ & 2.795 \\
\%Weight gain & $5678.65 \pm 35.98^{\mathrm{a}}$ & $5167.54 \pm 15.3^{\mathrm{b}}$ & $4293.27 \pm 40.94^{\mathrm{c}}$ & 49.029 \\
SGR (\%/day) & $3.38 \pm 0.0 \mathrm{I}^{\mathrm{a}}$ & $3.30 \pm 0.00 \mathrm{Ib}^{\mathrm{b}}$ & $3.15 \pm 0.0 \mathrm{I}^{\mathrm{c}}$ & 0.015 \\
$\begin{array}{l}\text { Survival (\%) } \\
\text { FCR }\end{array}$ & $94.75 \pm 0.354^{\mathrm{a}}$ & $93 \pm 0.707^{\mathrm{a}}$ & $90.5 \pm 0.707 \mathrm{~b}$ & 1.378 \\
$\begin{array}{l}\text { Fish production } \\
\text { kg/decimal/4 }\end{array}$ & $0.883 \pm 0.0057^{\mathrm{a}}$ & $0.971 \pm 0.0035^{\mathrm{b}}$ & $1.168 \pm 0.0113^{\mathrm{c}}$ & 0.004 \\
months & $62.42 \pm 0.62^{\mathrm{a}}$ & $55.85 \pm 0.26^{\mathrm{b}}$ & $45.33 \pm 0.78^{\mathrm{c}}$ & 0.891 \\
\hline
\end{tabular}

In column, Mean followed by the same letter (s) did not differ significantly at 0.0llevel.

Lsd= Least Significant Differences, FCR= Food Conversion Ratio, SGR=Specific Growth Rate

\section{Weight gain}

There was no significant $(\mathrm{p}<0.01)$ difference in initial weight of fish in different treatment. The weight gain of fish was $323.68 \pm 2.05$, $294.55 \pm 0.87$ and $244.72 \pm 2.33 \mathrm{~g}$ for $\mathrm{T}_{1}, \mathrm{~T}_{2}$ and $\mathrm{T}_{3}$, respectively. The significantly $(\mathrm{P}<0.01)$ highest weight gain $(323.68 \mathrm{~g})$ was found in fish having feeding frequency four times and lowest weight gain (244.72 g) was found in fish having feeding frequency two times.

\section{Percent weight gain}

There was no significant $(p<0.01)$ difference in initial weight of fish in different treatment. The percent weight gain of fish was $5678.65 \pm 35.98 \%$ for $\mathrm{T}_{1}, 5167.54 \pm 15.31 \%$ for $\mathrm{T}_{2}$ and $4293.27 \pm 40.94 \%$ for $\mathrm{T}_{3}$. The significantly $(\mathrm{P}<0.01)$ highest percent weight gain $(5678.65 \%)$ was observed in $T_{1}$ having feeding frequency four times.
The minimum percent weight gain $(4293.27 \%)$ was observed in $\mathrm{T}_{3}$ having feeding frequency two times.

\section{Specific growth rate (SGR \% per day)}

The values of specific growth rate of monosex tilapia were observed as, $3.38 \pm 0.01,3.30 \pm 0.001$ and $3.15 \pm 0.01$ in treatment $T_{1}$, $\mathrm{T}_{2}$ and $\mathrm{T}_{3}$, respectively. There were significant $(\mathrm{P}<0.01)$ differences among the different treatments. SGR progressively increased with the increase in feeding frequency. The significantly highest specific growth rate (3.38) was observed in $\mathrm{T} 1$, might be due to the fact that the fish have utilized effectively the supplied feed taking small amount at a rate of four times in a day. The lowest specific growth rate (3.15) was observed in $\mathrm{T}_{3}$.

\section{Survival (\%)}

The survivability of monosex tilapia was observed as $94.75 \pm 0.354$, $93 \pm 0.707$ and $90.5 \pm 0.707 \%$ in $\mathrm{T}_{1}, \mathrm{~T}_{2}$ and $\mathrm{T}_{3}$, respectively. The highest survivability was recorded in treatment $\mathrm{T}_{1}$ and the lowest survivability was in $T_{3}$. The little variation of survivability was occurred due to environmental condition and feeding frequency. In $\mathrm{T}_{1}$ feeding frequency was four times in a day so the feed utilization rate was high and the survivability was also high. A more or less similar survival rate was observed by Rahman $\mathrm{MM}^{20}$ who recorded survival rate ranged from 94 to $95 \%$.

\section{Food conversion ratio (FCR)}

Food conversion ratio (FCR) value of the diet used for feeding fry, at different frequencies of four times, three times and two times a day were found as $0.883,0.971$ and 1.168 , respectively. The mean least FCR value 0.883 was found in $T_{1}$ where the fish fed with a frequency four times daily. The highest mean FCR value 1.168 was found in T3 where fry fed two times daily.

\section{Production (kg/dec/4 months)}

The production was observed to be $62.42 \pm 0.62,55.85 \pm 0.26$ and $45.33 \pm 0.78 \mathrm{~kg} / \mathrm{dec} / 4$ months in $\mathrm{T}_{1}, \mathrm{~T}_{2}$ and $\mathrm{T}_{3}$, respectively. The significantly $(\mathrm{P}<0.01)$ highest fish production was obtained $62.42 \pm 0.62$ $\mathrm{kg} / \mathrm{dec} / 4$ months in $\mathrm{T} 1$ under four times feeding frequencies and production was found to be decreased significantly with the decrease in feeding frequencies. The lowest fish production $45.33 \pm 0.78 \mathrm{~kg} /$ dec/4 months was observed in $\mathrm{T}_{3}$ under two times feeding frequencies which might be due to ineffective feed utilization bulk ration at a time and resulting decreased feed efficiency (Figure 1).

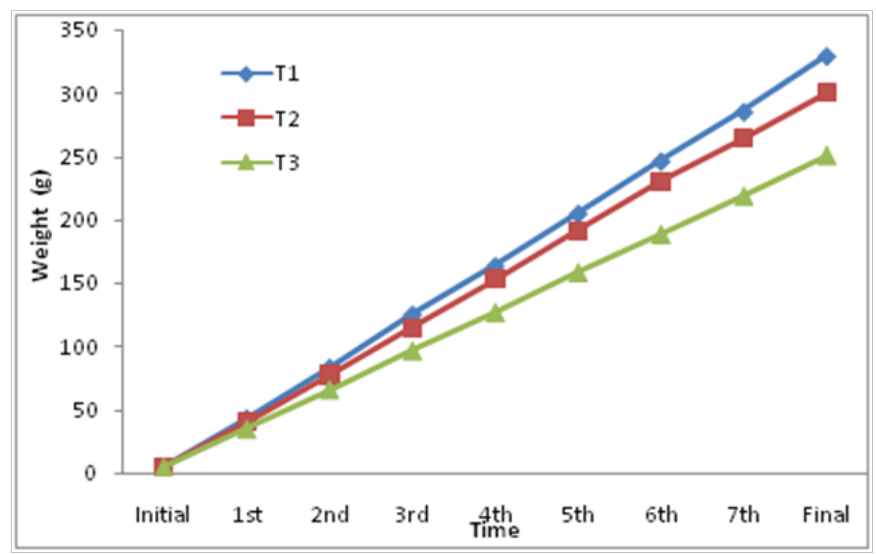

Figure I Growth of monosex tilapia in terms of increase in weight $(g)$ in different treatments during experimental period. 
In the present study, a commercial feed (Mega feed) was used for Monosex Tilapia farming under field conditions by feeding fish at different feeding time and frequencies. During the study period, physico-chemical parameters and growth parameters have also been observed. Growth, feed efficiency and feed consumption of fish are normally governed by few environmental factors. ${ }^{21-22}$ The water quality parameters measured during the study period were within the acceptable limit for fish culture. Water temperature found during the study period is more or less similar in different treatments. The maximum temperature $32^{\circ} \mathrm{C}$ was recorded in treatment $T_{2}$ on 21 August whereas the minimum $\left(27.1^{\circ} \mathrm{C}\right)$ was in $\mathrm{T}_{2}$ on November 11 , which might be due to low strength of sunlight which is very close to the findings of. ${ }^{23}$ The DO content in water was revealed 4.2 to 6.6 $\mathrm{mg} / \mathrm{l}$ during the study period in all the treatment ponds. Kohinoor AHM \& Hossain MY ${ }^{24,25}$ reported more or less similar results where the DO values of fish ponds ranged from 3.8 to $6.9 \mathrm{mg} / \mathrm{L}$ and 2.04 to $7.5 \mathrm{mg} / \mathrm{L}$ respectively. The range of $\mathrm{pH}$ in the experimental ponds was recorded to be slightly alkaline $6.98-8.3$. This is within the acceptable range required for fish culture 6.5-9.0. ${ }^{26}$ During the experimental period, three feeding frequency were applied to observe the growth performance of tilapia. The mean final weight of tilapia was 329.38 $\mathrm{g}$ for $\mathrm{T} 1,300.25 \mathrm{~g}$ for $\mathrm{T}_{2}$ and $250.42 \mathrm{~g}$ for $\mathrm{T}_{3}$. The mean weight gain of $323.68,294.55$ and $244.72 \mathrm{~g}$ and mean percent weight gain of $5678.65,5167.54$ and $4293.27 \%$ and mean SGR of 3.38, 3.30 and $3.15 \%$ were recorded in $\mathrm{T}_{1}, \mathrm{~T}_{2}$ and $\mathrm{T}_{3}$, respectively. The highest weight gain, percent weight gain and SGR were found in $T_{1}$ which might be due to the effect of having four times feeding frequencies in a day which indicate the effective utilization of feed. The lowest were found in $\mathrm{T}_{3}$ having feeding frequency two times a day. The survival rate was $94.75,93$ and $90.5 \%$ in $\mathrm{T}_{1}, \mathrm{~T}_{2}$ and $\mathrm{T} 3$, respectively. FCR values were $0.883,0.971$ and 1.168 in $\mathrm{T}_{1}, \mathrm{~T}_{2}$ and $\mathrm{T}_{3}$, respectively. The best FCR value was obtained in $T_{1}$ where fry were fed with four times feeding frequency. The production was observed to be $62.42,55.85$ and 45.33 $\mathrm{kg} / \mathrm{dec} / 4$ months in $\mathrm{T}_{1}, \mathrm{~T}_{2}$ and $\mathrm{T}_{3}$, respectively. The significantly $(\mathrm{P}<0.01)$ highest fish production was obtained $62.42 \mathrm{~kg} / \mathrm{dec} / 4$ months in $\mathrm{T}_{1}$ under four times feeding frequencies and production was found to be decreased significantly with the decrease in feeding frequencies. The lowest fish production $45.33 \mathrm{~kg} / \mathrm{dec} / 4$ months were observed in $\mathrm{T}_{3}$ under two times feeding frequencies.

\section{Conclusion}

Based on the above discussion, the highest mean weight gain, survival and production was observed in $\mathrm{T}_{1}$ treatment which is under four times feeding frequencies. However, further investigation should be carried out for sustainable monosex tilapia culture in Bangladesh and evolve a definite pond culture technology of monosex tilapia culture. Therefore, it might be concluded that feeding frequency played a vital role on the growth and production performance of monosex tilapia (Oreochromis niloticus).

There was a believe that if fishes are given $1 \%$ feed on their body weight at a time perform good growth, but now a days we found that increased feeding frequency played better result on the growth and production of monosex male tilapia. However, further investigation should be carried out for sustainable monosex tilapia culture in Bangladesh and we hope it would also helps to evolve a definite pond culture technology of monosex tilapia culture in our country.

\section{Acknowledgements}

None.

\section{Conflicts of interest}

None.

\section{References}

1. Pandian TJ. Protein requirements of fish and prawns cultured in Asia. In: De Silva (Ed.), Fish Nutrition Research in Asia. Proceedings of the $3^{\text {rd }}$ Asian Fish Nutrition Network Meeting, Asian Fisheries Society, Philippines. 1989;pp.11-22.

2. NRC (National Research Council), Nutrient requirements of fish. National Academy Press, USA. 1993.

3. Phillips TA, Summerfelt RC, Clayton RD. Feeding frequency effects on water quality and growth of walleye fingerlings in intensive culture. Progres Fish-Culturist. 1998;60:1-8.

4. Wang N, Hayward RS, Noltie DB. Variation in food consumption, growth, and growth efficiency among juvenile hybrid sunfish held individually. Aquaculture. 1998;167(1-2):43-52.

5. Brett JR, Groves TDD. Physiological Energetics. In: Fish physiology (Eds.), WS Hoar, DJ Randall Vol. VIII, Academic Press, USA. Pp.1979;.279-352.

6. Reddy SR, Katre S. Growth rate and conversion efficiency of the air breathing catfish, Hetropneustes fossilis, in relation to ration size. Aquaculture. 197918(1):35-40.

7. Hung SSO, Lutes PB. Optimum feeding rate of hatchery-product juvenile white sturgeon (Acipenser transmontanus) at $20^{\circ} \mathrm{C}$. Aquaculture. 198765(3-4):307-317.

8. Hung SSO, Conte FS, Hallen EF. Effects of feeding rates on growth, body composition and nutrient metabolism in striped bass (Morone saxatilis) fingerlings. Aquaculture. 1993;112(4):349-361.

9. Lovell RT. Feeding practices. In: Nutrition and feeding of channel catfish, Southern Cooperative series. 1977;218:50-55.

10. De Silva SS, Davy FB. Fish nutrition research for semi-intensive culture system in Asia. Asia Fisheries Science. 1992;5(1992):129-144.

11. Murai T, Andrews JW. Effect of frequency of feeding on growth and food conversion of channel cat fish fry. Bull. Jap Soc Sci Fish. 1976;42(2):159-161.

12. Chiu YN, Sumagaysay NS, Sastrillo MGS. Effect of feeding frequency and feeding rate on the growth and feed efficiency of milk fish, Chanoschanos(Forskal) juveniles. Asian Fish. Sci. 1987;1:27-31.

13. Nunez JD, Donos TG. Feeding strategies of Salmonid cages and residuals assessment in lake Rupanco. Osorno, Chile. Medio. Ambiente. $1995 ; 12: 76-81$.

14. Jarboe HH, Grant WJ. The influence of feeding time and frequency on the growth, survival, feed conversion and body composition of channel catfish, Ictalurus punctatus, cultured in a three tier, close recirculating raceway. J. Appl. Aquaculture. 1997;7(1):13-62.

15. Lim CE, Webster CD. Tilapia: biology, culture, and nutrition. The Haworth Press Inc., 10 Alice Street, Bringhamton, USA. 2006;pp.13904-1580.

16. Chowdhury DK. Optimal feeding rate for Nile tilapia (Oreochromisniloticus), M.Sc thesis, Department of Animal and Aquacultural Sciences, Norwegian University of Life Sciences, UK. 2011;p.1-76.

17. Gupta MV, Ahmed M, Bimbao MA, et al. Socio-economic impact and farmers Assessment of Nile Tilapia (O. niloticus) culture in Bangladesh. ICLARM technical Report No. 35. International Center for Living Aquatic Resources Management, Philippines, pp. 1992;50.

18. Kohinoor AHM, Modak PC, Hussain MG. Growth and Production performance of red Tilapia and Nile Tilapia under low input culture system. Bangladesh J. Fish Res. 1998;3(1):11-17.

19. Horwitz W. Official Methods of Analysis of the Association of Official Analytical Chemists (14 ${ }^{\text {th }}$ edn), Association of Official Analytical Chemists. Washington DC, USA. Pp. 1984;1018. 
20. Rahman MM. Effect of addition of calbaush (Labeocalbasu) in the periphyton based aquaculture system of rohu and catla. MS dissertation, Department of Fisheries Management, BAU, Bangladesh. 2000.

21. Fry FE. The effect of environmental factors on the physiology of fish. In: WS Hoar \& DJ Randall (Eds.), Fish Physiology, Environmental relations and Behaviour. Academic Press, USA. Pp. 1971;1-98.

22. Brett JR. Environmental factors and growth. In: Haor WS \& Randall DJ (Eds.), Fish Physiology, Environmental relations and behaviour. Academic Press, USA, pp. 1979;599-677.

23. Wahab MA, Ahmed ZF, Islam MA, et al. Effect of introduction of common carp, Cyprinuscarpio L., of the pond ecology and growth of fish in polyculture. Aquacult. Res. 2001;26(9):619-628.
24. Kohinoor AHM. Development of culture technology of three indigenous fish mola (Amblypharyn godonmola), Punti (Puntiussophore) \& Chela (Chela cachius) with notes on some aspects of their biology, $\mathrm{Ph} . \mathrm{D}$ dissertation, Department of Fisheries Management, BAU, Bangladesh, pp. $2000 ; 363$.

25. Hossain MY. Effects of iso-phosphorus organic and inorganic fertilizer on water quality parameters and biological production. MS Thesis, Department of Fisheries Management, BAU, Bangladesh, pp. 2000;74.

26. Boyd CE. Water quality in ponds for Aquaculture. Birmingham Publishing Co., Birmingham, USA. 1990;pp.482. 